\title{
PERKEMBANGAN PERBANKAN SYARIAH (2009-2018) \\ DI INDONESIA DAN SUMBER DAYA MANUSIANYA
}

\author{
Oleh: Thalha Alhamid \\ (SYA.155037) \\ Ekonomi Syariah \\ Sekolah Tinggi Agama Islam Negeri (STAIN) Sorong Tahun 2019 \\ Email: syarifahalhamid225@gmail.com
}

\section{Pendahuluan}

Perkembangan industri perbankan syariah di Indonesia mengalami pasang surut seiring dengan perkembangan industri perbankan konvensional.. Hingga saat ini perbankan syariah masih terus berjuang mempertahankan eksistensinya dalam industri keuangan, dengan proses perkembangannya yang cukup menakjubkan meskipun bila dibandingkan dengan negara-negara yang tercatat dalam Islamic Finance Country Index, Indonesia terbilang berjalan ditempat.

Seiring perkembangannya, dunia perbankan syariah juga mengalami berbagai macam masalah diantaranya permasalahan likuiditas, sumber daya manusia, pangsa pasar, dll. Faktor-faktor inilah yang membuat pergerakan industri perbankan syariah di Indonesia kian melambat. Salah satu aspek penting dalam manajemen suatu industri/perusahaan adalah Sumber Daya Manusia (SDM). Jika dalam suatu manajemen memiliki problema terkait SDM nya, minimal akan mempengaruhi kinerja perkembangan perusahaan tersebut. Dalam dunia perbankan khususnya, peran SDM sangat penting, sehingga dibutuhkan SDM yang kompeten dan professional baik persoalan teoritis maupun praktisinya. Maka, penulisan artikel ini bertujuan untuk mereview perjalanan perbankan syariah di Indonesia selama sepuluh tahun terakhir dan bagaimana sumber daya manusianya dibalik perkembangan industrinya.

\section{Dinamika Perkembangan Perbankan Syariah di Indonesia}

Perbankan syariah mulai diakui eksistensinya pada saat dikeluarkannya UU No.7 Tahun 1992 tentang bank yang menerapkan konsep bagi hasil, meskipun tidak disebutkan secara jelas terkait prinsip syariahnya. Semenjak itu Bank Muamalat yang merupakan bank Islam pertama mulai beroperasi di Indonesia. Eksistensi perbankan syariah semakin kuat ketika disahkannya UU No.10 Tahun 1998 sebagai amandemen dari UU No.7 Tahun 1992. Dalam undang-undang yang diperbaharui tersebut disebutkan secara jelas bahwa Bank Umum maupun Bank Perkreditan Rakyat yang beroperasi secara konvensional dan/atau berdasarkan prinsip syariah. Lalu kemudian pada tahun 2008, 
disahkannya UU No.21 Tahun 2008 oleh Presiden Susilo Bambang Yudhoyono tentang Perbankan Islam, dimana regulasi ini yang digunakan sampai saat ini.

Dibalik perkembangan regulasi perbankan syariah, terekam sebuah fakta bahwa kemunculan perbankan dengan sistem syariah ini sebagai jawaban atas permintaan masyarakat Indonesia yang menginginkan bank bebas bunga. Akan tetapi setelah dilegalkan beroperasi di Indonesia pada tahun 1992, perbankan syariah tidak berkembang dengan pesat. Setelah itu muncul fakta baru yang mengejutkan bahwa perbankan syariah merupakan lembaga keuangan yang sehat dan tetap stabil ketika runtuhnya kurs mata uang. Seperti yang diketahui bahwa pada tahun 1997- 1998 terjadi krisis moneter yang mengakibatkan kerugian besar-besaran pada industri keuangan di Indonesia. Namun, pada masa itu Perbankan Syariah justru menunjukkan ketangguhannya dengan hanya mengalami kerugian secara operasional, sebaliknya perbankan konvensional mengalami negative spread (Nurul Huda dan Mohammad Heykal, 2010) . Tragedi jatuhnya eksistensi perbankan konvensional ini berimbas pada tatanan ekonomi nasional yang mengakibatkan hilangnya kepercayaan masyarakat pada perbankan Indonesia saat itu.

Pergolakan politik dan moneter yang terjadi tidak memberikan dampak yang begitu buruk, dapat dilihat dimana perbankan syariah semakin berkompetisi didunia finansial dengan tetap menjaga tingkat stabilitasnya dari persaingan yang tidak sehat. Tercatat dalam Otoritas Jasa Keuangan (OJK) Syariah bahwa perbankan syariah mempunyai jaringan sebanyak 1.868 Bank Umum Syariah (BUS), 347 Unit Usaha Syariah (UUS), dan 289 Bank Pembiayaan Rakyat Syariah (BPRS) pada tahun 2018 (Tabel 1). Meskipun memiliki jaringan yang cukup banyak, namun secara spesifik jaringan kantor perbankan syariah masih sedikit tersebar di beberapa daerah, bagian Indonesia Timur khususnya .

Jika dilihat pada jendela nasional, Perbankan syariah yang bersaing dengan perbankan konvensional memang berkembang cukup pesat. Meskipun perkembangan lembaga perbankan syariah setiap periode mengalami tingkat perkembangan yang fluktual. Apabila melihat pada jendela internasional, dalam Islamic Finance Country Index(GIFR, 2017) tercatat bahwa Indonesia menempati ranking ke-7 setelah Malaysia, Iran, Saudi Arabia, United Arab Emirates, dan Kuwait. Sedangkan pada 2016 Indonesia menempati ranking ke-6, yang berarti minus satu ranking. Industri keuangan syariah memang terbilang berjalan ditempat jika dibandingkan dengan negara-negara tersebut. Disisi lain, data tersebut membuktikan bahwa Indonesia memiliki potensi dan peluang yang besar untuk perkembangan industri perbankan syariah kedepannya, mengingat Indonesia adalah negara dengan populasi penduduk muslim terbesar di dunia. 
Tabel 1. Perkembangan lembaga perbankan syariah di Indonesia periode 2009-2018

\begin{tabular}{|c|c|c|c|c|c|c|c|c|c|c|}
\hline \multirow{2}{*}{ Indikator } & \multicolumn{10}{|c|}{ Periode } \\
\cline { 2 - 12 } & $\mathbf{2 0 0 9}$ & $\mathbf{2 0 1 0}$ & $\mathbf{2 0 1 1}$ & $\mathbf{2 0 1 2}$ & $\mathbf{2 0 1 3}$ & $\mathbf{2 0 1 4}$ & $\mathbf{2 0 1 5}$ & $\mathbf{2 0 1 6}$ & $\mathbf{2 0 1 7}$ & $\mathbf{2 0 1 8}$ (Jan-Nov) \\
\hline BUS & 717 & 1.226 & 1.052 & 1.756 & 2.009 & 2.163 & 1.990 & 1.869 & 1.825 & 1.868 \\
\hline UUS & 312 & 285 & 360 & 541 & 613 & 320 & 311 & 332 & 344 & 347 \\
\hline BPRS & 363 & 436 & 519 & 559 & 565 & 276 & 283 & 287 & 274 & 289 \\
\hline $\begin{array}{c}\text { Asset (miliar } \\
\text { Rp) }\end{array}$ & 66.090 & 97.519 & 145.467 & 195.018 & 242.276 & 272.343 & 296.262 & 356.504 & 424.181 & 451.202 \\
\hline $\begin{array}{c}\text { DPK (miliar } \\
\text { Rp) }\end{array}$ & 52.271 & 76.036 & 115.415 & 147.512 & 183.534 & 217.859 & 231.175 & 279.333 & 334.888 & 354.421 \\
\hline
\end{tabular}

Sumber : Otoritas Jasa Keuangan Syariah (2009-2018)

Keterangan :

BUS (Bank Umum Syariah)

UUS (Unit Usaha Syariah)

BPRS (Badan Pembiayaan Rakyat Syariah)

DPK (Dana Pihak Ketiga)

\section{SDM Perbankan Syariah di Indonesia}

Permasalahan sumber daya manusia ini sudah bukan lagi hal yang baru didunia industri perbankan syariah. Sejauh ini, yang diketahui bahwa kualitas sumber daya manusia perbankan syariah berkembang dengan cukup baik diikuti dengan perkembangan industrinya. Akan tetapi, dalam beberapa studi penelitian membuktikan bahwa permasalahan yang paling menonjol dalam dunia perbankan syariah adalah masalah sumber daya manusianya.

Aam Slamet Rusydiana mengemukakan bahwa salah satu faktor yang menjadi penghambat berkembangnya industri perbankan syariah di Indonesia adalah belum memadainya sumber daya manusia yang terdidik dan professional (Rusydiana, 2016). Menurut Amirus Sodiq, faktor yang pertama adalah lemahnya pemahaman praktisi bank syariah, baik sisi pengembangan bisnis maupun sisi syariah. Dengan kata lain belum terpenuhinya sumber daya insani yang mumpuni dibidang ekonomi syariah, sehingga dalam praktiknya perbankan syariah seringkali menyimpang dari prinsip syariah. Kedua, supply oriented. Praktisi hanya bisa menjelaskan apa yang mereka tahu tetapi tidak bisa menjawab apa yang ditanyakan oleh masyarakat. Ketiga, belum memadainya sumber daya manusia yang terdidik dan profesional, terutama teknis manajerial (Sodiq, 2017).

Sedangkan menurut Muhammad Tho'in, hasil penelitiannya menunjukkan bahwa pada tingkatan manajer di Bank BNI Syariah Surakarta, pemahaman tentang produk-produk syariah serta pemahaman terhadap prinsip-prinsip syariah sudah sangat baik, karena hal itu didukung oleh faktor pendidikan, pelatihan dan pengalaman yang cukup berperan secara signifikan. Sedangkan pada tingkat karyawan, justru bertolak belakang dari tingkatan manajer dikarenakan faktor pendidikan, pelatihan dan 
pengalaman yang belum mumpuni (Tho'in, 2016). Ini berarti bahwa perkembangan kualitas sumber daya manusia perbankan syariah belum bisa mengikuti perkembangan dari segi kuantitasnya. Perkembangan SDM perbankan syariah selama sepuluh periode terakhir mengalami fluktuasi namun tidak menurun secara drastis (Tabel 2).

Potret kualitas SDM perbankan syariah yang kerap dikatakan sebagai kendala ternyata hanya dari aspek kompetensi yang belum mumpuni baik secara teoritis maupun praktisinya. Bagaimanapun, industri perbankan syariah sudah berusaha seoptimal mungkin untuk mencapai visi misi dalam pengembangan SDM nya.

Tabel 2. Perkembangan Tenaga Kerja Perbankan Syariah Periode 2009-2018

\begin{tabular}{|c|c|c|c|c|c|c|c|c|c|c|}
\hline \multirow{2}{*}{ Indikator } & \multicolumn{10}{|c|}{ Periode } \\
\cline { 2 - 11 } & $\mathbf{2 0 0 9}$ & $\mathbf{2 0 1 0}$ & $\mathbf{2 0 1 1}$ & $\mathbf{2 0 1 2}$ & $\mathbf{2 0 1 3}$ & $\mathbf{2 0 1 4}$ & $\mathbf{2 0 1 5}$ & $\mathbf{2 0 1 6}$ & $\mathbf{2 0 1 7}$ & $\mathbf{2 0 1 8}$ (Jan-Nov) \\
\hline $\begin{array}{c}\text { Tenaga Kerja } \\
\text { BUS }\end{array}$ & 10.348 & 15.224 & 21.820 & 24.111 & 26.717 & 41.393 & 51.413 & 51.110 & 51.068 & 52.345 \\
\hline $\begin{array}{c}\text { Tenaga Kerja } \\
\text { UUS }\end{array}$ & 2.296 & 1.868 & 2.067 & 3.108 & 11.511 & 4.425 & 4.403 & 4.487 & 4.678 & 4.349 \\
\hline $\begin{array}{c}\text { Tenaga Kerja } \\
\text { BPRS }\end{array}$ & 2.799 & 3.172 & 3.773 & 4.359 & 4.826 & 4.704 & 5.102 & 4.372 & 4.619 & 4.749 \\
\hline
\end{tabular}

Sumber : Otoritas Jasa Keuangan Syariah (2009-2018)

\section{Penutup}

Perbankan syariah perlu lebih optimal lagi mengarahkan rencana-rencana strategisnya untuk pengembangan industri kedepannya, baik strategi pengembangan produk perbankan syariah, strategi manajemen sumber daya manusia, dan strategi operasional lainnya. Mengingat Indonesia merupakan negara mayoritas muslim terbesar di dunia, maka cukup potensial untuk mengembangkan keuangan syariahnya diera globalisasi ini. Akan tetapi, tidak hanya memfokuskan pada perkembangan kinerja keuangannya saja melainkan juga menempatkan fokus perkembangannya pada manajemen dan kualitas SDM nya, agar proses akselerasi perbankan syariah antara perkembangan industri dan kualitas SDM perbankan syariah berkesesuaian. 


\section{Daftar Pustaka}

Alamsyah, H. (2012). Perkembangan dan prospek perbankan syariah Indonesia: Tantangan dalam menyongsong MEA 2015. Makalah disampaikan pada Ceramah Ilmiah Ikatan Ahli Ekonomi Islam (IAEI), Milad ke-18 IAEI,(13 April 2012).

Nuruddin, A. (2010). SDM Berbasis Syariah. Tsaqafah, 6(1), 27-42.

Rama, A. (2015). Analisis Deskriptif Perkembangan Perbankan Syariah di Asia Tenggara. Journal of Tauhidinomics, 1(1), 1-25.

Rusydiana, A. S. (2016). Analisis Masalah Pengembangan Perbankan Syariah di Indonesia: Aplikasi Metode Analytic Network Process. Esensi: Jurnal Bisnis dan Manajemen, 6(2), 237-246.

Sari, M. D., Bahari, Z., \& Hamat, Z. (2013). Perkembangan Perbankan Syariah di Indonesia: Suatu Tinjauan. Jurnal Aplikasi Bisnis, 3(2), 120-138.

Sodiq, Amirus. "Analisis SWOT Perkembangan Perbankan Syariah Di Indonesia." MALIA: Journal of Islamic Banking and Finance 1.1 (2018).

Syukron, A. (2013). Dinamika Perkembangan Perbankan Syariah di Indonesia. Economic: Journal of Economic and Islamic Law, 3(2), 28-53.

Tho'in, M. (2016). Kompetensi Sumber Daya Manusia Bank Syariah Berdasarkan Prinsip-Prinsip Syariah Islam (Studi Kasus Pada BNI Syariah Surakarta). Jurnal Ilmiah Ekonomi Islam, 2(03).

Utama, A. S. (2018). Sejarah dan Perkembangan Regulasi Mengenai Perbankan Syariah Dalam Sistem Hukum Nasional Di Indonesia. Jurnal Wawasan Yuridika, 2(2), 187-200.

Zubair, M. K. (2008). Akselerasi Pertumbuhan Bank Syariah di Indonesia. Millah: Jurnal Studi Agama, $8(1), 1-16$.

http://www.gifr.net/publications/gifr2017/ifci.pdf\&sa=U\&ved=2ahUKEwjXmdiM9YfgAhXJPI8KHY msA-QQFjAAegQIAhAB\&usg=AOvVaw0dHGeUdOATAb0Qrl8kSzjs

https://www.ojk.go.id/id/kanal/syariah/data-dan-statistik/statistik-perbankan-syariah/Default.aspx\# https://www.ojk.go.id/id/kanal/syariah/tentang-syariah/Pages/Perbankan-Syariah.aspx 